\title{
ESG Investing: The Use of ESG Ratings in a Smart Beta Strategy*
}

\author{
Balázs Stempler
}

ESG investing has recently been growing in popularity but the range of investment products available could still be widened. One possible approach is a combination of ESG ratings and the smart beta strategy that modifies index weighting based on a factor; thus, it contains elements from both active and passive fund management. The hypothetical funds created in this paper using this method achieved returns of over 50 per cent between 2015 and 2019, while the benchmark EURO STOXX 50 only provided a 19 per cent profit for investors during the five-year period. ESG ratings were found to be significant as a variable, suggesting that they can influence returns but other factors such as size or earnings growth have higher explanatory power. Also, while currently the possibilities for ESG investments are limited in Hungary, market players are starting to realise the potential of ESG, and with the suggested approach new investors could be attracted by funds.

Journal of Economic Literature (JEL) codes: G11, G15, G23, G24

Keywords: ESG investing, fund management, stock indices, smart beta

\section{Introduction}

ESG $^{1}$ investing has been expanding rapidly in terms of volume as investors are becoming more conscious of the allocation of their savings. In this paper, I examine how fund managers can fulfil this demand from their clients with a new product type.

In order to determine the environmental, social, and governance performance of a company, ESG ratings are created by agencies. However, these ratings can have more applications than just filtering out the laggard firms. The goal of this paper is to show a way in which stronger focus could be put on ESG ratings with the use of

\footnotetext{
* The papers in this issue contain the views of the authors which are not necessarily the same as the official views of the Magyar Nemzeti Bank.

Balázs Stempler is a Finance MSc Student at Budapest University of Technology and Economics. E-mail: stemplerbalazs@gmail.com

An earlier version of this paper won 1st place in the 2020 MNB-BME Research Competition in the green financing questions category. I would like to thank András Póra and Dr. András Bethlendi for their guidance throughout the process.

The English manuscript was received on 7 September 2020.
}

DOI: http://doi.org/10.33893/FER.20.2.91116

${ }^{1}$ ESG: environmental, social, governance 
the smart beta investing strategy, aiming for both higher returns and encouraging companies to try to perform better in socially important areas.

The paper showcases an investment area that is becoming more and more popular every year, and it helps to understand how fund managers can improve their services and shift to a more socially desirable way of conducting business even in a highly profit-oriented industry. I seek to understand the influence of ESG ratings on returns and I also show the method's applicability to the current Hungarian fund market.

\section{The concept of ESG investing and its popularity}

ESG investing refers to the use of ESG factors in the selection of companies for investment, i.e. putting more focus on those that function in a "socially responsible" way. The abbreviation comes from the three areas that are considered regarding the organisation's impact: environmental, social, and governance activity. ESG investing was born in a society that came to believe that focusing solely on generating profit should not be the way any company operates. Nowadays, when climate change is becoming an issue in our everyday life and news regarding mistreatment of workers can reach the majority of our population in minutes, a corporation that disregards social topics in favour of more profit puts its reputation at risk.

As ESG aspects in society became more and more important, they were soon incorporated into investment decisions as well. According to an Ernst \& Young information material ${ }^{2}$, since 2012 ESG investing has grown by 107 per cent every year and in 201718 per cent of assets belonged to such investments. The inflow of capital to ESG funds has increased even more in the last few years: lacurci ${ }^{3}$ reports that in 2019 USD 20.6 billion were invested in mutual funds and exchangetraded funds that focus on ESG investing, which is four times larger than the amount in 2018. The report also identifies that the number of funds that offer such investments has increased to over 300 globally.

Alongside ESG investing, there are several terms that are often used interchangeably in discussions, such as sustainable investing, socially responsible investing (SRI), green investing and ethical investing. They share a common goal: to make investment decisions based on more than just profitability. However, differences between these approaches can be found. Socially responsible investing is rooted in the principal social issues of the last century (e.g. the civil rights movement

\footnotetext{
${ }^{2}$ Sustainable Investing: the millennial investor. Ernst \& Young, 2017. https://www.ey.com/Publication/ vwLUAssets/ey-sustainable-investing-the-millennial-investor-gl/\$FILE/ey-sustainable-investing-themillennial-investor.pdf. Downloaded: 28 December 2020.

${ }^{3}$ lacurci, G.: Money moving into environmental funds shatters previous record. CNBC. https://www.cnbc. com/2020/01/14/esg-funds-see-record-inflows-in-2019.html. Downloaded: 28 December 2020.
} 
and the opposition to the Vietnam War in the USA), and is based solely on values, unlike modern ESG which uses non-traditional data to assess company performance (Townsend 2020). Ethical investing resembles SRI due to its focus on morality, while green investing refers only to the environmental pillar of ESG. Finally, sustainable investing is generally concerned with the goal of sustainable development, i.e. meeting present needs without compromising the ability of future generations to do the same. A less common but nonetheless relevant investment strategy is investing based on religious beliefs. The idea is to select only companies that are in line with for example Christian or Islamic values. Faith-based investing can be considered a subset of socially responsible investing, which bases its values on religion.

In general, there are three different methods to conduct ESG investing:

1. Negative screening: avoiding investments in companies that operate in a sector that damages the environment or society,

2. Positive screening: selecting companies that are known best for their responsible operations,

3. Impact investing: finding a desirable goal and investing in companies working on achieving that goal.

Obviously, negative screening filters out only certain areas, whereas positive screening and impact investing can restrict investments to an even smaller number of possibilities. While all of these approaches put more focus on ESG considerations than regular investment strategies, ESG investing should be considered on a scale because of the many options to choose from, and it is recommended to be clear whether we mean best-in class selection or negative screening when we talk about the topic.

Unsurprisingly, young generations especially favour the sentiment of ESG investing as issues such as climate change and social equality are closer to their mindset. Apparently, 95 per cent of millennials find ESG investing appealing, but it is also important to note than they are the not the only ones: 85 per cent of all answers express some interest in the concept ${ }^{4}$. However, age is far from being the only factor that affects the attractiveness of ESG investing as gender, income, and education can also impact investors' attitude towards this investment strategy (Cheah et al. 2011).

The moral benefit of ESG investing is undoubtable; if investors cannot go to bed knowing that their money is used to finance destructive operations, ESG investing

\footnotetext{
${ }^{4}$ Morgan Stanley Survey Finds Investor Enthusiasm for Sustainable Investing at an All-Time High. 12 September 2019. https://www.morganstanley.com/press-releases/morgan-stanley-survey-finds-investor-enthusiasmfor-sustainable-. Downloaded: 28 December 2020.
} 
becomes not merely an option to consider but the only option. However, since not every investment decision is based on morality, more aspects need to be reviewed.

As already mentioned, ESG-oriented strategies restrict the number of available instruments for investment which logically leads to missing out on those returns as well. Furthermore, the number of industries excluded from the investment range can have a significant impact on the risk-adjusted returns, suggesting that there is an opportunity cost to negative screening (Trinks - Scholtens 2015). As highlighted by Muller $^{5}$, some companies can claim to be environmentally and socially responsible but use it only as a marketing trick instead of actually functioning that way (e.g. the Volkswagen diesel scandal), which is often referred to as "greenwashing". Also, what is considered acceptable from an ESG standpoint is not set in stone. The topic is subjective and widely discussed among thinkers which makes any decision about ESG more complex. From a financial point of view, an additional factor to bear in mind is that if extreme restrictions are applied to the portfolio, concentration risk increases due to the lack of proper diversification (Arribas et al. 2019).

However, on the other side of the argument it can be claimed that filtering out companies does not necessarily reduce returns. For example, Bernow et al. (2017:3) point out that reputational damage can be a major risk-factor for companies. By filtering out those companies that are likely to face lawsuits, pay fines for their actions or have their brands associated with bad behaviour, investors can actually increase their returns by not having these stocks in their portfolio.

\begin{tabular}{|c|c|c|c|c|c|}
\hline \multicolumn{6}{|c|}{$\begin{array}{l}\text { Table } 1 \\
\text { Returns of selected indices and their ESG versions }\end{array}$} \\
\hline Index name & 2016 & 2017 & 2018 & 2019 & $\begin{array}{c}\text { Cumulative } \\
\text { return }\end{array}$ \\
\hline S\&P 500 & $9.5 \%$ & $19.4 \%$ & $-6.2 \%$ & $28.9 \%$ & $58.08 \%$ \\
\hline S\&P 500 ESG Index & $9.9 \%$ & $18.7 \%$ & $-5.9 \%$ & $30.6 \%$ & $60.32 \%$ \\
\hline FTSE 100 & $16.8 \%$ & $13.1 \%$ & $-9.5 \%$ & $19.2 \%$ & $48.80 \%$ \\
\hline FTSE 100 ESG Select & $20.4 \%$ & $10.7 \%$ & $-8.9 \%$ & $17.7 \%$ & $42.91 \%$ \\
\hline MSCI ACWI & $7.9 \%$ & $24.0 \%$ & $-9.4 \%$ & $26.6 \%$ & $53.46 \%$ \\
\hline MSCI ACWI ESG Index & $7.2 \%$ & $24.1 \%$ & $-9.3 \%$ & $28.0 \%$ & $54.45 \%$ \\
\hline
\end{tabular}

\footnotetext{
${ }^{5}$ Muller, C. (2020): The Pros and Cons of Socially Responsible Investing. DoughRoller. https://www.doughroller. net/investing/pros-and-cons-of-socially-responsible-investing/. Downloaded: 28 December 2020.
} 
According to an Etergino Group report ${ }^{6}$ in 2018, between 2009 and 2017 the MSCl ACWI ESG Index produced almost identical returns ( 0.1 percentage point higher per annum) than the original $\mathrm{MSCl}$ ACWI Index which captures the performance of many developed and emerging equity markets. In the MSCI ACWI ESG Index, there were 1,904 stocks selected, while the non-ESG index had 2,450 components in 2017. The ESG index removes companies with the weakest ESG profiles and changes the original weighting as well. The similarity of results may indicate that the reduction of options for investment consideration is offset by the effect of decreasing operational and reputational risks associated with better ESG profiles.

To obtain a slightly more representative picture, I collected the most recent annual returns of three indices at the time of writing and compared them to their ESG versions (Table 1). The difference is larger than the 0.1 per cent mentioned earlier but overall, the returns are still similar on a yearly basis. The trend based on the data seems to be that if the ESG index outperformed or underperformed the original index in one year, the opposite would happen in the following year. While the ESG version of the S\&P 500 outperformed its benchmark, the returns of the FTSE 100 were not matched by its modified version. The difference between the above mentioned $\mathrm{MSCl} \mathrm{ACWI}$ and its ESG counterpart was the least significant among the three pairs.

The previously quoted statistics reflect usual market conditions. On the other hand, the Covid-19 pandemic and its initial negative effect on stock markets give us a chance to look at stressed economic circumstances, to see how ESG performs when the economic outlook worsens. As a consequence of the global pandemic, in March 2020 stock markets suffered some of their worst days ever recorded. Under market stress, the focus of investment turns to safe havens such as gold and USD, while investors that stay on the stock market shift their attention (and capital) to defensive stocks that outperform cyclical assets in a downturn. If the use of ESG can actually reduce risks, ESG-conscious corporations should have outperformed the general market under these conditions. Hale compared the first-quarter returns of 206 funds and found that ESG-focused ones performed better. 70 per cent of ESG funds achieved better than average returns in their markets and only 11 per cent of such funds belonged to the worst quartile based on performance. He examined the geographic distribution as well: 10 of 12 US ESG funds managed to beat their benchmark, on average by over 1 percentage point, while in other developed markets each ESG fund outperformed its benchmark, with a surplus return of close to 2 percentage points. He found that a contributing reason to the phenomenon is that ESG funds do not include, or at least underweight, some stocks in the energy

\footnotetext{
${ }^{6}$ The Benefits of ESG Investing: How Socially Responsible Investing Can Drive Outperformance. Etergino Group, 2017. https://us.rbcwealthmanagement.com/documents/170410/170426/18-WG-774_Etergino+Group Benefits+of+ESG+Investing+Flyer_evite.pdf/2f645a56-155e-4b55-8bc2-3e1a61fc84b6. Downloaded: $2 \overline{8}$ December 2020.
} 
sector that did especially poorly in March. However, he notes that this observation is only secondary in significance based on his attribution analysis. The primary reason, according to him, is that companies with higher ESG ratings treat their stakeholders better and function in a more responsible way which makes them perfect candidates to survive unexpected shocks ${ }^{7}$.

\section{ESG ratings}

\subsection{The benefits of ESG ratings}

If investors wish to invest their capital based on ESG considerations, they face a time-consuming obstacle, as it can be a cumbersome task to determine how ESG-friendly a company is in reality. An initial negative screening seems to be the simplest part; some industries can be excluded objectively from ESG investing, e.g. tobacco. However, after having determined an industry-level classification, a company-specific decision proves to be more difficult.

An organisation might build its brand to appear focused on ESG, which creates an unconscious bias in the individual who makes the investment decision. This bias can only be overcome with detailed research which is difficult for multiple reasons:

1. Companies are motivated to highlight positive views about themselves in their reports, while possibly attempting to bury potentially damaging information about their environmental or social performance. Such practices were uncovered in the energy sector by Talbot - Boiral (2018).

2. Regulations differ significantly among regions and countries. The European Union (in the Non-Financial Reporting Directive) requires large companies to publish sustainability reports based on international or national standards, such as the ISO 26000 or OECD guidelines, while in the United States corporate sustainability reports are not mandatory. These reports could serve as one of the sources of ESG information but sustainability reporting still often contains only a few, poorly detailed figures which are not enough for investors to make a well-founded decision ${ }^{8}$.

3. Companies usually use metrics that are considered important in their own industry, making the situation even more complicated for investors who do not possess considerable knowledge of several industries.

\footnotetext{
${ }^{7}$ Hale, J. (2020): Sustainable Funds Weather the First Quarter Better Than Conventional Funds. Morningstar. https://www.morningstar.com/articles/976361/sustainable-funds-weather-the-first-quarter-better-thanconventional-funds. Downloaded: 28 December 2020.

${ }^{8}$ What investors want to know about ESG metrics. EY Reporting, 2018. https://www.ey.com/en_gl/assurance/ what-investors-want-to-know-about-esg-metrics. Downloaded: 28 December 2020.
} 
All of these difficulties can be understood as advantages of ESG ratings which are made by analysts specialised in particular businesses. With ESG ratings, all the complex, time-consuming tasks are left to professionals who translate them into a final figure that summarises the company's ESG performance. The end-user (whether it is a retail investor or a fund manager) only needs to make sure that the methodology used by the rating agency is in line with their expectation and can then comfortably rely on the result.

\subsection{ESG rating agencies and the $\mathrm{MSCl}$ rating methodology}

The emergence of ESG rating organisations preceded the substantial volume surge in ESG investing seen in the last few years. By 2010 there were already ten agencies providing this service. Back then, these agencies differed significantly in their rating methodologies and not a single industry was unanimously excluded by them; areas were often only marked as "controversial" (Escrig-Olmedo et al. 2010). The agencies also took into account different standards, some basing judgement on e.g. ISO standards, the Kyoto protocol and/or the UN Declaration of Human Rights.

However, the ESG rating industry has changed since its inception. Douglas et al. (2017) highlighted that the industry underwent consolidation, thanks to several acquisitions that were made in order to provide more comprehensive services to customers. Some of the ten specialised agencies examined in 2010 still operate, but larger market players that provide additional databases appeared, indicating how the inclusion of previously rarely considered ESG factors became a part of mainstream investment decisions.

Such database providers include Bloomberg, FTSE Russell, $\mathrm{MSCl}$ and Thomson Reuters. They offer ESG ratings, decomposition of individual factors and several indices (Douglas et al. 2017:5). To access the details of their calculations, one must pay a fee, but $\mathrm{MSCl}$, unlike its competitors, provides the final ratings free of charge, thus making its service attractive for retail investors as well, while fund managers and professional investors will have access to these databases anyway.

A recent publication finds that, compared to one decade ago, agencies have improved their models by including new criteria to better reflect new challenges, but the process is still not perfect and one should always become familiar with the details of the methodology used before accepting the final results (Escrig-Olmedo et al. 2019). 
$\mathrm{MSCl}$ provides an overview of its methodology on its website which I will now summarise to understand how final ESG ratings are decided ${ }^{9}$. The other goal of this demonstration is to introduce this methodology due to its relevance to the investing strategy I later discuss.

$\mathrm{MSCl}$ assesses ESG performance based on both quantitative and qualitative data. They identified 37 Key Issues that could expose an organisation to ESG risks, but they also provide an opportunity if those risks are managed properly. The Key Issues belong to environmental, social and governance pillars. The pillars are then divided into ten themes: climate change, natural resources, pollution \& waste and environmental opportunities in the environmental pillar; human capital, product liability, stakeholder opposition and social opportunities in the social pillar; and corporate governance and corporate behaviour in the governance pillar. The issues considered to be key are reviewed every year and updated if necessary.

Key Issues are weighted differently based on two factors on an industry level: the level of contribution to environmental and social impact, and the expected time frame for the risk/opportunity to materialise. According to MSCl's example, a high impact and short-term issue has a three-times higher weight than a low impact, long-term issue.

For each Key Issue, both the level of risk exposure and the quality of risk management are taken into account to determine how a company fares in an industry. The idea behind this is that if a company has high exposure to some risk (for example using outdated, polluting technologies), higher risk mitigation is required from their management, whereas a company with low exposure can get away with moderate risk management. Controversies are also given attention: based on the scale and nature of the impact, every event is categorised and assigned a weight to include into the final calculation. $\mathrm{MSCl}$ also gives organisations the chance to offer additional data to obtain a more comprehensive picture of the firm's activity.

The final result is a rating between AAA and CCC. Similar to credit ratings, AAA is considered the best. Each of the seven ratings covers one seventh of the 0-10 scale which is the final result of the calculations committed. Currently thousands of equities are rated, reviewed, and updated on a yearly basis. The final ESG rating, the rating history, the rating distribution in the industry, and examples of areas where a company performs well and poorly are available free of charge but to access to weights and detailed scores, one must pay a premium.

\footnotetext{
${ }^{9}$ MSCI ESG Research (2019): ESG Ratings. Measuring a company's resilience to long-term, financially relevant ESG risks. https://www.msci.com/documents/1296102/14524248/MSCl+ESG+Ratings+Methodology+-+Exec+Summary+2019.pdf/2dfcaeee-2c70-d10b-69c8-3058b14109e3?t=1571404887226. Downloaded: 28 December 2020.
} 


\section{Smart beta investing}

\subsection{Active and passive fund management, and the concept of smart beta}

Traditionally, we can differentiate between two categories of portfolio management: active and passive. Actively managed funds usually aim to outperform their benchmark, or they have a particular investment objective. Active investing builds on the abilities to select stocks and time the market, which are challenging tasks, and thus such fund managers charge relatively high management fees for their expertise. On the other hand, the goal of passive fund management is to replicate the returns of a market index as closely as possible; therefore, the allocation of the investment is based on the composition of an index, while active investors can employ more unique strategies. With passive investing, there is no need to perform extensive research into industries and prices, and thus the fees of such funds are much lower than those of actively managed funds.

The argument for investing in actively managed funds is the possibility to outperform the market. However, in the last ten years only 23 per cent of active funds managed to beat their passive counterpart. Riquier also highlights the large differences between market segments: only 8 per cent of US large blend funds (that invest in both US large-cap value stocks and growth companies) were able to outperform their benchmark, while 82 per cent of funds that invest in non-US small and medium capitalisation firms $\mathrm{did}^{10}$. The stock picking and market timing skills of fund managers have been thoroughly examined by researchers, leading to varying results depending on the frequency of data and the time horizon used (Rompotis 2009).

\footnotetext{
${ }^{10}$ Riquier, A. (2019): More evidence that passive fund management beats active. Marketwatch. https:// www.marketwatch.com/story/more-evidence-that-passive-fund-management-beats-active-2019-09-12. Downloaded: 28 December 2020.
} 


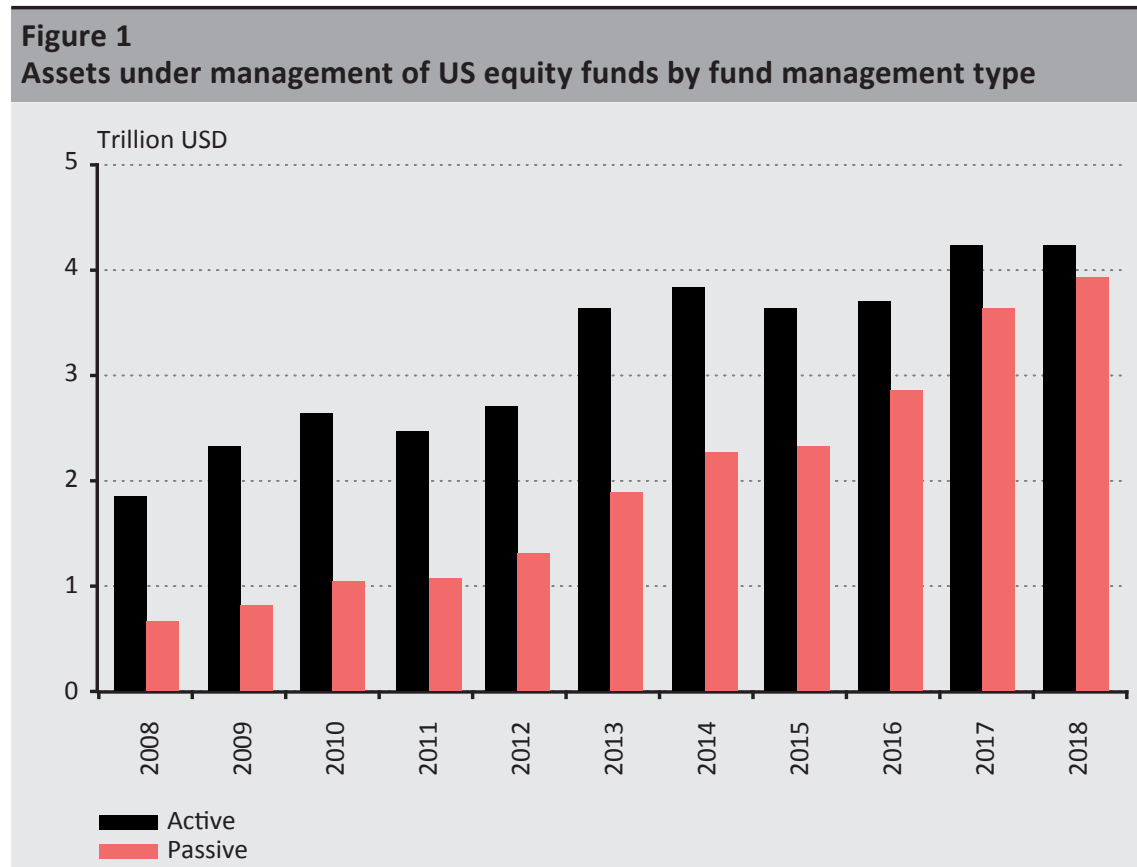

Source: Stein, C.: Shift From Active to Passive Approaches Tipping Point in 2019. Bloomberg article, 31 December 2018. https://www.bloomberg.com/news/articles/2018-12-31/shift-from-active-to-passiveapproaches-tipping-point-in-2019. Downloaded: 28 December 2020.

Passive investing has become more popular in recent decades: first, it was the theory of efficient markets that gave this approach a theoretical foundation, then the appearance of index funds and decreasing costs motivated investors to rethink their need for actively managed portfolios. The increasing popularity of passive investing shown in Figure 1 is accompanied by the growth of ETFs, which are mostly used as a passive investing tool by investors to replicate the returns of an index. They have been growing steadily in the last decade as well and are now responsible for one third of the trading activity in the USA. USD 3.5 trillion was allocated to them over the last ten years, which shows how significant they have become ${ }^{11}$. It should be noted though that the recent success of passive investing occurred in a long bull market and during most market corrections active managers tend to perform better ${ }^{12}$. The shift from active to passive investing also has impacts on the financial system, including increased industry concentration, the effect of index-inclusion, and amplified volatility due to leveraged and inverse ETFs (Anadu et al. 2020).

${ }^{11}$ Flood, C.: Popularity of passive investing changes rules of the game. Financial Times, 22 October 2019. https://www.ft.com/content/3cc857e0-d0c0-11e9-b018-ca4456540ea6. Downloaded: 28 December 2020.

${ }^{12}$ Friedmann, C. (2020): To Be Active Or Passive During The Coronavirus Crisis. The Wealth Advisor, 6 May. https://www.thewealthadvisor.com/article/be-active-or-passive-during-coronavirus-crisis. Downloaded: 28 December 2020. 
Smart beta investing offers a third option alongside active and passive fund management. Its name refers to beta which is the measurement of volatility in finance. The beta of index tracking funds equals one in theory and these funds only carry systemic risk as they have the same composition as the market benchmark, while the beta of active funds is based on the construction of the portfolio and active investing also involves idiosyncratic risk. The name of the smart beta strategy is technically not related to this financial measure, instead it is used only as a marketing tool for a type of investment product.

The strategy originates from the fact that most market indices are market capitalisation weighted. As market cap is the product of the number of shares outstanding and the current stock price, the higher these figures are the larger their weight will be in the index. This approach may be counterintuitive for investors that do not follow a momentum-based investing strategy, i.e. they do not wish to allocate more of their savings to a security when its price increases (all else remaining unchanged).

With the market cap-based index weighting system, the value of an index is concentrated in a handful of securities of companies with very high market capitalisation. At the beginning of 2020, Apple, Microsoft, Alphabet, Amazon and Facebook accounted for 17.5 per cent of the S\&P 500, undermining the goal of the index, which is to provide exposure to a well-diversified US market (Levy - Konish 2020). This ratio increased further during the rally following the crash in March, reaching 24 per cent by the end of August.

Smart beta modifies the weights of index components, i.e. under or overweighting them compared to their exposure in the benchmark index. The modified weights are based on a factor that is believed to be closely related to higher returns. There are many options for the selection of such a factor (e.g. size, volatility or dividend yield) and sometimes more than one factor is used. 


\begin{tabular}{|c|c|c|c|}
\hline \multicolumn{4}{|c|}{$\begin{array}{l}\text { Table } 2 \\
\text { Comparison of the characteristics of active and passive fund management, and smart } \\
\text { beta }\end{array}$} \\
\hline & Active fund management & $\begin{array}{l}\text { Passive fund } \\
\text { management }\end{array}$ & Smart beta investing \\
\hline $\begin{array}{l}\text { Basis for } \\
\text { investment }\end{array}$ & $\begin{array}{l}\text { Consideration of the fund } \\
\text { manager }\end{array}$ & Tracks an index & Based on selected factors \\
\hline Management fees & Relatively high & $\begin{array}{l}\text { Significantly less than for } \\
\text { active funds }\end{array}$ & $\begin{array}{l}\text { Lower than for active } \\
\text { funds }\end{array}$ \\
\hline Rebalancing & $\begin{array}{l}\text { Consideration of the fund } \\
\text { manager }\end{array}$ & $\begin{array}{l}\text { Only if the composition of } \\
\text { the index changes }\end{array}$ & $\begin{array}{l}\text { When the factor values } \\
\text { change }\end{array}$ \\
\hline Risk profile & Idiosyncratic risk & Systemic risk & Modified systemic risk \\
\hline Transparency & $\begin{array}{l}\text { Investment decisions are } \\
\text { not necessarily } \\
\text { communicated }\end{array}$ & Highly transparent & $\begin{array}{l}\text { Investing is based on } \\
\text { a predefined rule }\end{array}$ \\
\hline
\end{tabular}

Smart beta combines elements of both passive and active funds, and its characteristics are shown in Table 2. It can be considered passive because it follows a rule which defines exactly how the money allocation is performed. However, as it deviates from the original composition of the index, it can be thought of as active investing. Its risk profile is closer to that of passive investing as it uses the constituents of some benchmark index but by modifying the weights it deviates from pure systemic risk by a certain degree.

Smart beta portfolios require some management because the factor has to be determined, and the weights must be calculated and have to be rebalanced when the values of the factor change (usually on a yearly or quarterly basis depending on the selected factor); thus, the management fees should exceed those of passive funds but should be lower than active fund fees. This theory seems to be consistent with practice as well; Rabener ${ }^{13}$ found that the average expense ratio of smart beta funds is around 0.3 per cent which is between the asset-weighted average expense ratios in the USA of 0.13 per cent and 0.66 per cent for passive and active funds, respectively ${ }^{14}$.

Unlike managers of active funds, smart beta managers do not make decisions based on their judgement as they have to follow the selected factor at all times, making such funds more transparent than active funds where investors do not always know beforehand or agree with the decisions of the portfolio manager.

${ }^{13}$ Rabener, N. (2020): Factor Scoring Smart Beta ETFs. Factorresearch.com, January 2020. https://www. factorresearch.com/research-factor-scoring-smart-beta-etfs. Downloaded: 28 December 2020.

${ }^{14}$ Liu, E. (2020): Investing Gets Cheaper as Fund Fees Continue to Fall. Barron's, 9 June. https://www. barrons.com/articles/mutual-fund-fees-etf-passive-investing-financial-advice-morningstar-51591719173. Downloaded: 28 December 2020. 


\subsection{ESG as a smart beta factor}

The emergence of the smart beta philosophy and the rising demand for ESG investment opportunities can be combined to offer new products for investors. ESG in smart beta may sound attractive to those that wish to gain access to a diversified stock (or bond) portfolio but do not like the fact that large indices include companies or industries that cause damage to the environment or mistreat their employees, or if they wish to achieve higher returns than passive ESG funds.

Funds have already been created that use some ESG criteria in a smart beta strategy, and researchers have started to derive ESG performance factors from broad data sources (e.g. Giese et al. 2016, Bender et al. 2017). According to a recent survey, the percentage of asset owners with smart beta strategies that look to apply some ESG considerations to their method increased from 40 to 60 percent since 2017, signalling the growth of ESG in this product type as well ${ }^{15}$.

Since ESG ratings are widely available, the weights can be based upon them. It is up to the fund manager to decide the weight of each rating, and thus multiple versions can be established, ranging from a mild modification (where the weights of different rating classes are close to each other) to a drastic overhaul with a large tracking error. The latter option can be subject to criticism if many companies are completely excluded from the index (i.e. have a weight of zero) which can lead to higher concentration risk (Pfeuti 2019) ${ }^{16}$. On the other hand, the former approach might only seem like a weak attempt to appear ESG friendly. As the preference of customers is not uniform, several such fund versions are recommended to be created to allow investors to choose the one they prefer. Based on the nature of smart beta investing, the cost of maintaining multiple funds should not be too high and would enable more investors to find a suitable fund, resulting in increased revenues for fund managers.

The idea behind a smart beta fund that is based on ESG ratings as a factor sounds justifiable from an ESG point of view, but if the returns are not competitive then they may never become popular. In the following section, I demonstrate what such a fund would look like and what performance it can be capable of.

\footnotetext{
${ }^{15}$ Fedorova, A.: Investors are marrying ESG with smart beta. ESG Clarity, 20 August 2020. https://esgclarity. com/ftse-russell-research-august-2020/. Downloaded: 28 December 2020.

${ }^{16}$ Pfeuti, E.: Smart Beta: Is this a match made in heaven? Funds Europe, December issue. https://www.fundseurope.com/dec-2019-jan-2020/smart-beta-is-this-a-match-made-in-heaven. Downloaded: 28 December 2020.
} 


\section{ESG weighted smart beta EURO STOXX 50}

In my example, I assigned weights to the companies in the EURO STOXX 50 index based on their MSCI ESG ratings. I chose this index because it covers several major European markets, includes many industries and each component has an $\mathrm{MSCl}$ ESG rating. The index is weighted by free-float market cap which will be of great importance to us.

\begin{tabular}{|c|c|c|c|c|c|c|c|c|c|c|}
\hline \multicolumn{11}{|l|}{ Table 3} \\
\hline \multirow[b]{2}{*}{ Rating } & \multicolumn{2}{|r|}{2015} & \multicolumn{2}{|r|}{2016} & \multicolumn{2}{|r|}{2017} & \multicolumn{2}{|r|}{2018} & \multicolumn{2}{|r|}{2019} \\
\hline & No. & $\begin{array}{c}\text { Of total market } \\
\text { cap }\end{array}$ & No. & $\begin{array}{c}\text { Of total market } \\
\text { cap }\end{array}$ & No. & $\begin{array}{c}\text { Of total market } \\
\text { cap }\end{array}$ & No. & $\begin{array}{c}\text { Of total market } \\
\text { cap }\end{array}$ & No. & $\begin{array}{c}\text { Of total market } \\
\text { cap }\end{array}$ \\
\hline AAA & 15 & $22.7 \%$ & 18 & $31.7 \%$ & 18 & $32.0 \%$ & 17 & $31.2 \%$ & 17 & $32.1 \%$ \\
\hline$A A$ & 12 & $24.9 \%$ & 12 & $22.7 \%$ & 9 & $18.0 \%$ & 8 & $17.1 \%$ & 8 & $13.6 \%$ \\
\hline A & 11 & $24.6 \%$ & 10 & $24.5 \%$ & 12 & $28.6 \%$ & 16 & $34.4 \%$ & 17 & $36.7 \%$ \\
\hline BBB & 10 & $22.8 \%$ & 8 & $17.1 \%$ & 9 & $17.6 \%$ & 6 & $11.0 \%$ & 5 & $12.0 \%$ \\
\hline BB & 0 & $0.0 \%$ & 0 & $0.0 \%$ & 1 & $1.5 \%$ & 2 & $3.6 \%$ & 2 & $3.2 \%$ \\
\hline$B$ & 1 & $1.5 \%$ & 1 & $1.6 \%$ & 0 & $0.0 \%$ & 0 & $0.0 \%$ & 0 & $0.0 \%$ \\
\hline $\mathrm{CCC}$ & 1 & $3.5 \%$ & 1 & $2.5 \%$ & 1 & $2.3 \%$ & 1 & $2.7 \%$ & 1 & $2.5 \%$ \\
\hline
\end{tabular}

Due to the significance of the index, all fifty of its components have had an MSCI ESG rating for at least five years. Table 3 provides an overview of how the ratings and the relative market caps changed between 2015 and 2019. The only company with a CCC rating is Volkswagen, which remained in the index despite suffering great reputational damage in the diesel scandal and losing the trust of many ESG investors. Overall, we can see that by 2019 the number of AAA-rated components increased, while some of the AA-rated companies in 2015 dropped to an A rating by 2019. A similar change can be observed from the market cap data as well, with AAA ratings becoming more substantial at the expense of AA ratings. The number and market cap of $A$ ratings also increased due to improvements in the rating by some BBB companies.

I created two portfolios: one will be referred to as the Mild ESG portfolio because the weights are not very different between ratings, whereas the other is more drastic and thus will be referred to as the Drastic ESG portfolio. The returns of the portfolios for a certain period can be obtained from the following weighting system:

$$
r_{\text {portfolio }}=\sum_{i=1}^{n} \frac{x_{i}}{\sum x} \cdot \frac{P_{t}-P_{t-1}}{P_{t-1}}
$$


where $n$ is the number of components in the index, $P_{t}$ is the closing price of the component in the period, $P_{t-1}$ is the closing price of the component in the previous period,

for the Mild ESG portfolio:

$$
x_{i}=\left\{\begin{array}{cc}
3 & \text { if rating }=A A A \\
2.5 & \text { if rating }=A A \\
2 & \text { if rating }=A \\
1.5 & \text { if rating }=B B B \\
1 & \text { if rating }=B B \\
0.5 & \text { if rating }=B \\
0 & \text { if rating }=C C C
\end{array}\right.
$$

for the Drastic ESG portfolio:

$$
x_{i}=\left\{\begin{array}{cc}
10 & \text { if rating }=A A A \\
5 & \text { if rating }=A A \\
2.5 & \text { if rating }=A \\
1.25 & \text { if rating }=B B B \\
0 & \text { if rating } \leq B B
\end{array}\right.
$$

The Mild ESG portfolio was weighted based on the following rule: in a given year, if a company had an AAA rating, it was given 3 points and for each rating below AAA 0.5 point was deducted. The reasoning behind this system was to assign a positive value to each class other than the weakest while keeping the difference between rating classes constant. The weights were then calculated by dividing a company's points with the sum of all points in that year. The Drastic ESG portfolio had a different point system: AAA equalled 10 points and the points were halved for each rating below $A A A$, while any rating less than $B B B$ equalled zero points in order to put more focus on higher ratings and exclude the worst rating classes.

In both portfolios, the weights change on a yearly basis based on what rating the company held that year and how other companies were rated. However, it should be noted that $\mathrm{MSCl}$ publishes ESG ratings for companies in multiple batches each year, so quarterly rebalancing might be necessary in practice. Also, in the Mild ESG portfolio any occurrence of a zero weight for a component with a non-CCC rating is due to the fact that no companies achieved that particular rating in that year, whereas in the Drastic ESG portfolio three rating categories are excluded from the original index portfolio which amounts to a total of two or three companies each year, while the Mild ESG portfolio only excludes one company out of fifty. This demonstrates that even the stricter portfolio does not considerably harm the principle of diversification. However, no companies were filtered out based on the industry they operate in, and thus several oil and gas companies are included in the portfolios which is debatable but at least they are only considered to the extent that their ESG rating allows. 


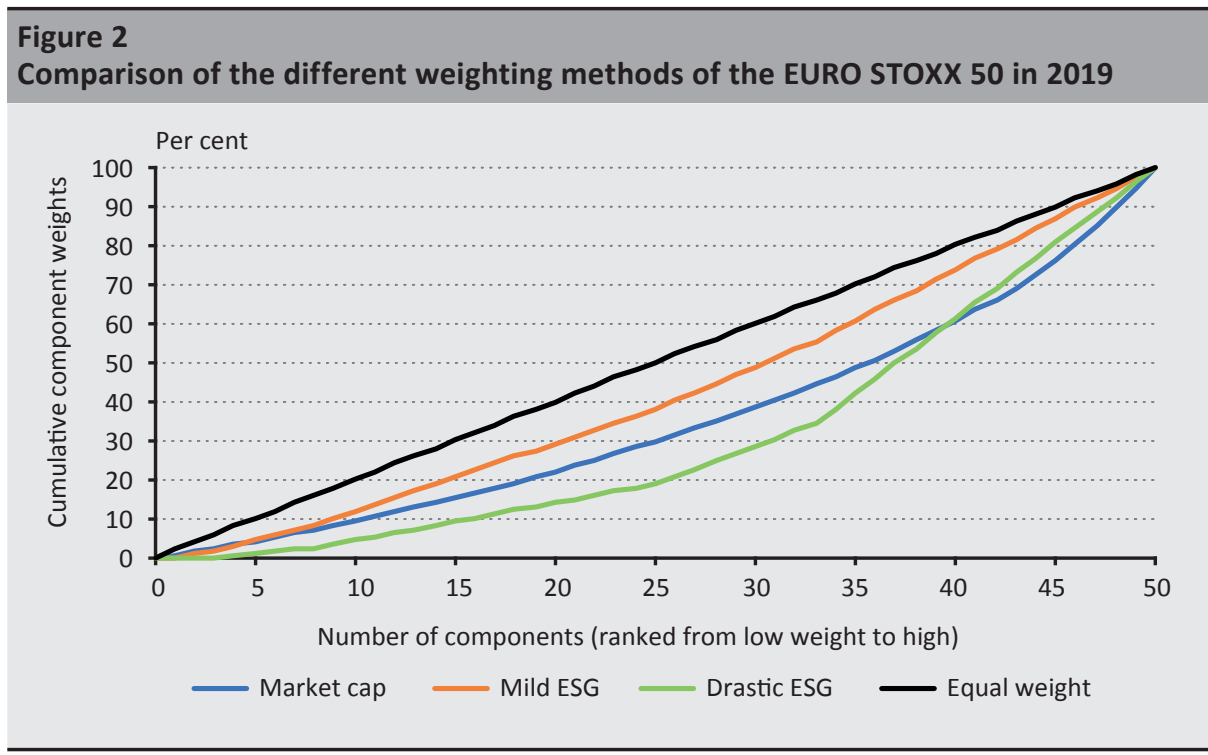

Figure 2 shows how the different weighting methods allocate weights to index components of the EURO STOXX 50. The Mild ESG portfolio is the closest to an equally weighted portfolio, while the Drastic ESG portfolio underweights those components that have a weak ESG rating more than the benchmark underweights those with small market cap. However, at the fortieth component these two methods intersect, and to the ten most impactful components the Drastic ESG portfolio assigns lower weights than the benchmark. This phenomenon shows that the Drastic ESG weighting method contributes less to the portfolio's performance being too reliant on a handful constituents than the benchmark. In the benchmark, the five largest companies in terms of market cap had a cumulative weight of 24 per cent in 2019, whereas in the Mild ESG portfolio the five best rated companies had a total weight of about 13 per cent and in the Drastic ESG portfolio the figure was around 19 per cent.

\section{Table 4}

Yearly returns of the EURO STOXX 50 and the two ESG portfolios between 2015 and 2019

\begin{tabular}{l|c|c|c|c|c|c|c|c}
\multicolumn{1}{c|}{ Portfolio } & $\mathbf{2 0 1 5}$ & $\mathbf{2 0 1 6}$ & $\mathbf{2 0 1 7}$ & $\mathbf{2 0 1 8}$ & $\mathbf{2 0 1 9}$ & $\begin{array}{c}\text { Cumulative } \\
\text { return }\end{array}$ & $\begin{array}{c}\text { Sharpe } \\
\text { ratio }\end{array}$ & $\begin{array}{c}\text { Sortino } \\
\text { ratio }\end{array}$ \\
\hline EURO STOXX 50 & $3.85 \%$ & $0.70 \%$ & $6.49 \%$ & $-14.34 \%$ & $24.78 \%$ & $19.03 \%$ & 0.30 & 0.66 \\
\hline Mild ESG & $11.79 \%$ & $6.58 \%$ & $11.52 \%$ & $-9.90 \%$ & $26.11 \%$ & $50.98 \%$ & 0.71 & 2.06 \\
\hline Drastic ESG & $12.68 \%$ & $8.37 \%$ & $12.38 \%$ & $-10.31 \%$ & $29.38 \%$ & $59.24 \%$ & 0.74 & 2.25 \\
\hline
\end{tabular}

The returns of the benchmark portfolio and the two ESG portfolios are shown in Table 4. It can be seen that both portfolios outperformed the original, market capweighted one by quite a large margin. The Mild ESG portfolio was only able beat 
the Drastic ESG portfolio once in the five-year period, when during the downturn in 2018 the price of AAA-rated companies fell more than the average, while both portfolios outperformed the benchmark in every year.

The better returns each year add up to a significant difference in the five-year period: the Drastic ESG portfolio achieved a return three times better than the benchmark, but even the Mild ESG portfolio beat the market by more than 31 percentage points. The risk-adjusted returns of the ESG portfolios were also significantly higher in the period. Though, as the two portfolios are merely hypothetical and not available for actual investment (i.e. no existing investment fund follows this logic), those that could not afford to buy each component were not able to achieve such returns. However, the returns would certainly justify the creation of such funds in practice as well. Under different market conditions, geographical locations, industries or weighting methodologies the outcomes could vary but in the case of the EURO STOXX 50 index between 2015 and 2019 it can be concluded that with the use of this ESG weighting system the returns would justify creating such funds as they could provide excess returns for investors while supporting ESG-related causes.

\section{Table 5}

Average return of each rating class between 2015 and 2019

\begin{tabular}{l|c|c|c|c|c}
\multicolumn{1}{c|}{ Rating } & $\mathbf{2 0 1 5}$ & $\mathbf{2 0 1 6}$ & $\mathbf{2 0 1 7}$ & $\mathbf{2 0 1 8}$ & $\mathbf{2 0 1 9}$ \\
\hline AAA & $14.12 \%$ & $12.59 \%$ & $13.50 \%$ & $-12.14 \%$ & $34.53 \%$ \\
\hline AA & $11.26 \%$ & $-1.89 \%$ & $10.74 \%$ & $-3.78 \%$ & $20.10 \%$ \\
\hline A & $11.36 \%$ & $4.27 \%$ & $7.86 \%$ & $-10.70 \%$ & $19.13 \%$ \\
\hline BBB & $5.12 \%$ & $4.32 \%$ & $13.15 \%$ & $-1.77 \%$ & $18.32 \%$ \\
\hline BB & $0.00 \%$ & $0.00 \%$ & $-12.38 \%$ & $-37.85 \%$ & $19.32 \%$ \\
\hline B & $52.85 \%$ & $12.57 \%$ & $0.00 \%$ & $0.00 \%$ & $0.00 \%$ \\
\hline CCC & $-20.99 \%$ & $-3.90 \%$ & $23.36 \%$ & $-17.55 \%$ & $24.55 \%$ \\
\hline
\end{tabular}

To better understand what drove these returns, it is worthwhile to look at the average return of each rating class. In Table 5 it can be seen that AAA-rated companies outperformed the other classes in four out of five years (excluding those classes that had only one component). The outperformance of components with an AAA rating and their frequency in the index explain why the deviation from the benchmark is so great. However, it is not apparent if the higher ESG rating was in fact the cause for the high returns of those components. To test this theory, I examined two other factors besides ESG ratings in the form of regression analysis (Equation 4).

$$
Y=\beta_{0}+\beta_{1} X+\epsilon
$$


The first factor was company size, with the book value of equity used as a proxy measure. Book value is often used in investing (especially the price-to-book ratio); however, other proxies would be acceptable as well (see Al-Khazali-Zoubi (2005) for more). The other variable examined was growth in earnings per share, while for the ESG ratings the weighting system of the Drastic ESG portfolio was used as it highlights that it is more difficult to improve a higher ESG rating than a lower one.

\section{Table 6}

Regression results of ESG rating, size, and earnings growth

\begin{tabular}{l|c|c|c} 
& ESG rating & Size & Earnings growth \\
\hline $\boldsymbol{\beta}_{\mathbf{0}}$ & -0.01005 & 0.11009 & 0.03116 \\
\hline $\boldsymbol{\beta}_{\mathbf{1}}$ & 0.00995 & -0.00173 & 0.22237 \\
\hline Standard error & 0.10834 & 0.09981 & 0.09980 \\
\hline $\mathbf{P}$-value & 0.0277 & 0.000378 & 0.000376 \\
\hline $\mathbf{R}^{\mathbf{2}}$ & $9.70 \%$ & $23.35 \%$ & $23.37 \%$ \\
\hline
\end{tabular}

Table 6 shows the results of the relevant regressions. With a p-value of 0.0277 , ESG ratings were found to be significant at $\alpha=0.05$ level, as were the other two variables. However, ESG ratings possessed low explanatory power compared to size and earnings growth, suggesting that those factors contributed more to the outperformance of the hypothetical funds. When the three factors were put into a single model, the p-value of ESG ratings increased above 0.05 but it was a significant variable at $\alpha=0.1$.

$$
\begin{gathered}
Y=0.07+0.01 \text { ESG rating }-0.0016 \text { Size }+0.20 \text { Earnings growth }+\epsilon \\
(0.0895) \\
(0.00016)
\end{gathered}
$$

The other two factors were still significant at $\alpha=0.05$. The three selected factors explain 45.4 per cent of the returns. This result shows that while ESG ratings should be included in investment decisions, one should consider other aspects as well.

These findings are in line with other studies examining ESG criteria in portfolios. Breedt et al. (2019) examined MSCI ESG ratings between 2007 and 2017 and found that while the ESG factor does not reduce returns, it also does not contribute to excess return, due to other factors (Small-minus-Big, momentum, and low beta) explaining the outperformance. In this study, the ESG factor was found to be significant for the EURO STOXX 50 but its contribution to the explanation of outperformance is limited, and secondary to that of size and earnings growth. A similar outcome was observed by Naffa - Fain (2020) who examined ESG megatrends and concluded that environmental megatrends (and one governance megatrend) could yield positive alphas, but the outperformance was explained by the variables of the Fama-French 5-factor model. 


\section{Application to the Hungarian market}

\subsection{ESG in Hungary and in the EU}

In general, the European Union focuses substantially on sustainability in terms of regulation and investment. Europe emerged as the leader in ESG investments and is still prominent in this area despite the increased interest in ESG all over the world. In 2012, ESG investments in Europe amounted to USD 8.8 trillion, accounting for 66 per cent of all ESG investments worldwide. By 2018 this ratio had fallen to 46 per cent, but the growth in European ESG investments (to USD 14.1 trillion) still put the continent ahead of all other regions ${ }^{17}$. This interest in ESG investments is expected to grow further in Europe due to new EU regulation anticipated to come into effect in 2021. This would mandate funds to make the ESG categorisation of their portfolios available for investors, putting pressure on fund managers and their senior management to assess the impact of their funds and make necessary alterations regarding their selection of investments in order to obtain a higher ESG classification. The importance of this issue could be quite high considering that institutional clients of the funds (e.g. pension funds) would have a difficult time explaining to their stakeholders why they decided to invest in socially destructive funds. As retail investors will not be directly affected by the regulation, they could theoretically invest in anything, but due to the increasing interest in ESG shown by the general public and the fact that fund managers would presumably not create products deliberately with a bad ESG classification (as they could expose their employer to reputational risk even if those did promise higher returns), it is expected that this segment will shift to being more ESG-intensive as well.

However, the situation in the EU is heterogeneous in this regard. The Scandinavian countries are often regarded as world leaders in ESG, both with companies and countries of the region topping the ESG leaderboards (Figure 3). The underlying cause of this phenomenon is often associated with the historical relationship of Nordic people with nature, but the real reason appears to be the combination of stronger "feminine" characteristics at the corporate level (e.g. focusing on consultation instead of competition and high status), more equal income distribution and higher transparency (Potter 2020) ${ }^{18}$.

${ }^{17}$ Ghosh, I.: Visualizing the Global Rise of Sustainable Investing. Visual Capitalist, 4 February 2020. https:// www.visualcapitalist.com/rise-of-sustainable-investing/. Downloaded: 28 December 2020.

${ }_{18}$ Potter, M.: Are Nordic businesses more sustainability conscious? Neste.com, 18 February 2020. https://www. neste.com/corporate-info/news-inspiration/articles/are-nordic-businesses-more-sustainability-conscious. Downloaded: 28 December 2020. 
As displayed in Figure 3, Hungary is a laggard in ESG on the continent, performing better than only Bulgaria and Romania. From an investing point of view, buying green equity is difficult in the country, not mainly because Hungarian companies operate in a less ESG-friendly way than anywhere else, but because most of them are not listed on the stock exchange, thus their securities cannot be purchased. As of 2020, only 37 Hungarian companies are listed on the Budapest Stock Exchange of which only 20 are in the Premium category. Even though the stock exchange, in association with financial institutions, is trying to promote the advantages of going public to companies, currently investors that seek to find ESG opportunities on the Hungarian market face the obstacle of not having a sizeable enough pool to choose from, which could lead to significant concentration risk. This notion is amplified by the fact that due to the low market cap of most publicly traded Hungarian firms, ESG rating agencies usually do not evaluate their performance, and thus they do not possess an ESG rating. For instance, $\mathrm{MSCl}$ assigned a rating only to the three largest publicly traded Hungarian companies (OTP, MOL, Richter) in 2020, which makes ESG investing in Hungary more difficult. This phenomenon can be observed in other emerging markets as well, requiring additional work from ESG rating agencies in the future in order to make ESG investing more widespread in these markets as well.
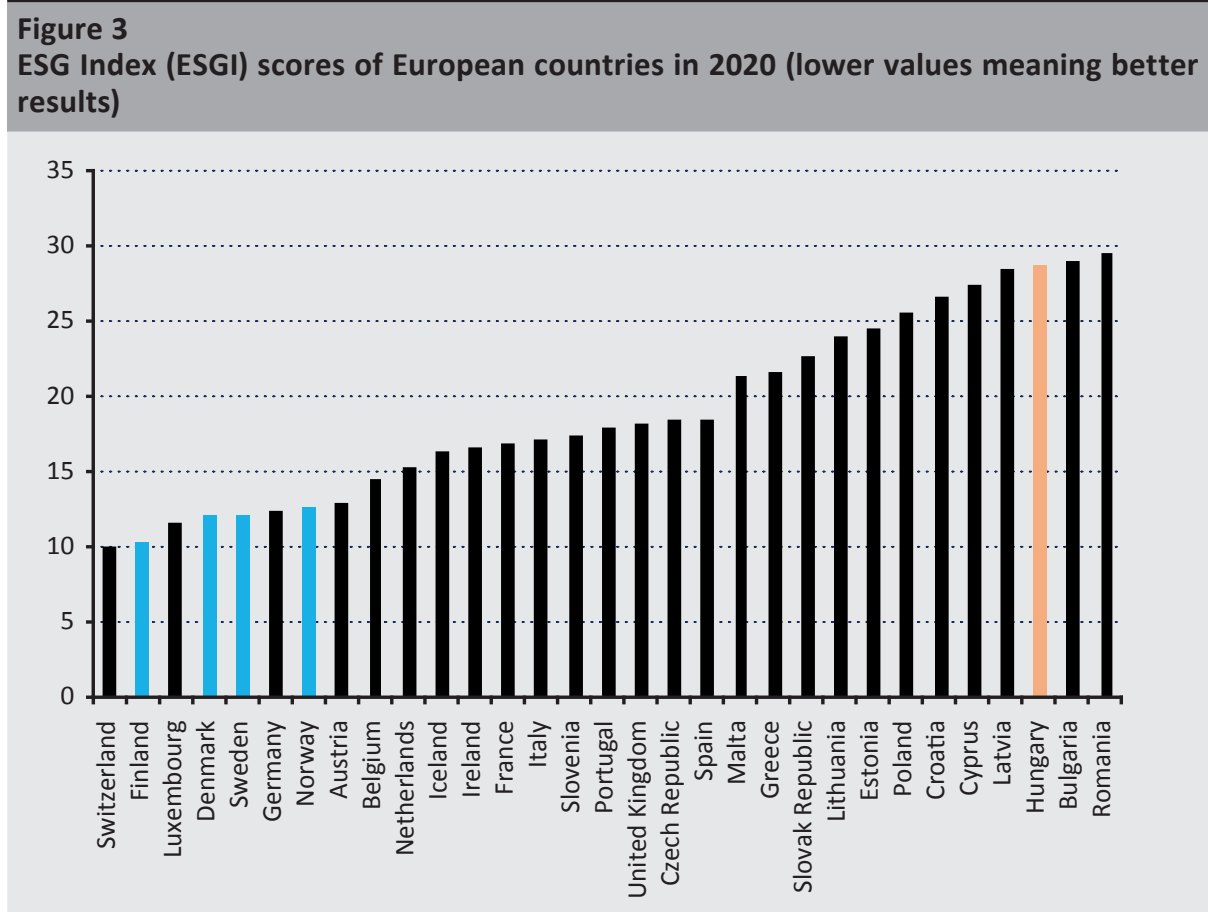

Source: https://risk-indexes.com/esg-index/. Downloaded: 28 December 2020. 


\subsection{Applicability of smart beta ESG investing for Hungarian funds}

The alternative to picking green stocks is investing in funds that do so for us. Certain asset management firms in Hungary offer some ESG funds but usually not more than one or two options. According to Zsuzsa Zobor, CEO of K\&H Fund Management, not many Hungarians are aware of ESG and the company only allocates a small portion of its assets to ESG investments, immaterial compared to the fact that 40 per cent of new investments of its Belgian parent company are related to ESG funds. ${ }^{19}$

She suggests that the Magyar Nemzeti Bank (the Central Bank of Hungary, MNB) should offer support by reducing the supervisory fee (which is basically a tax on funds) of ESG funds. Her recommendation is in line with the already ongoing activity of the MNB which tries to make finance greener in Hungary by offering consultations and education to increase the interest of households in the concept. Besides the $M N B$, other institutions are also working towards improving the country's ESG performance. In 2020, the first green bond issuances took place both on the government and corporate levels. These initiatives generated significant interest from the market, suggesting that steps taken towards ESG issues in the country may be worthwhile from a financial point of view as well. BAMOSZ (The Association of Hungarian Investment Fund and Asset Management Companies) also realised the increasing demand for ESG products and announced that from 2021 all Hungarian funds will be categorised based on ESG criteria. Funds that remove "unacceptable" securities from an ESG standpoint will be deemed ESG-qualified, while those that move beyond this approach and overweight assets with positive ESG performance can enter the ESG-plus category. The top category is ESG-impact, meant for funds that follow an impact investing strategy ${ }^{20}$ (BAMOSZ 2020).

Before this categorisation happens, investors face difficulties finding ESG funds. According to a consultation document issued by the MNB, only a few funds' names contain any reference to ESG, adding up to 0.4 per cent of the total asset value of the fund market (MNB 2019:11). The fact that an estimation could be made based only on a weak indicator such as the funds' name highlights that previously there was no database which contained ESG funds in Hungary, leading to a notion that Hungarian investors mostly lacked interest in such investments in the past. The authors of the aforementioned document seem to agree with this statement as they suggest that Hungarian retail investors should hold investments in ESG funds

\footnotetext{
${ }^{19} \mathrm{Xforest}$ interview with Zsuzsa Zobor, available at https://xforest.hu/befektetes-es-klimavaltozas/. Downloaded: 28 December 2020.

${ }^{20}$ Fenntartható fejlödéssel kapcsolatos minősítési szempontokkal egészült ki a befektetési alapok kategorizálása (Rating criteria related to sustainable development has been added to the Categorization of investment funds). BAMOSZ Press release. https://www.bamosz.hu/en/web/guest/hirek?p_p_id=62_

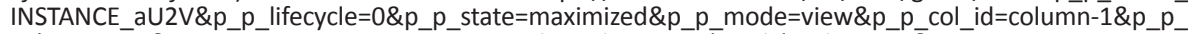
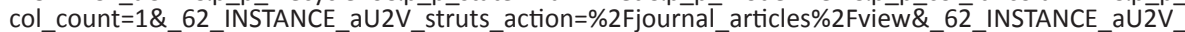

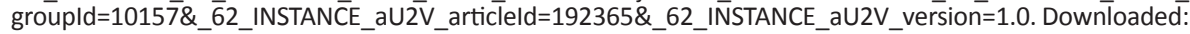
28 December 2020.
} 
for at least five years but that does not coincide with their usual behaviour as they mostly have low risk appetites (MNB 2019:12).

\section{Table 7}

ESG funds of the ten largest Hungarian fund management firms

\begin{tabular}{|c|c|c|c|c|c|}
\hline $\begin{array}{c}\text { Asset management } \\
\text { company }\end{array}$ & $\begin{array}{c}\text { Total assets } \\
\text { under } \\
\text { management in } \\
2019 \text { (mn HUF) }\end{array}$ & $\begin{array}{l}\text { Total ESG assets } \\
\text { under } \\
\text { management in } \\
2019 \text { (mn HUF) }\end{array}$ & $\begin{array}{c}\text { Share of ESG } \\
\text { funds from total } \\
\text { assets }\end{array}$ & $\begin{array}{c}\text { Number of ESG } \\
\text { funds in } 2019\end{array}$ & $\begin{array}{l}\text { New ESG funds } \\
\text { created in } 2020\end{array}$ \\
\hline OTP Fund Management & $1,073,448$ & 8,094 & $0.75 \%$ & 1 & 0 \\
\hline $\begin{array}{l}\text { Erste Fund } \\
\text { Management }\end{array}$ & $1,036,022$ & 0 & 0 & 0 & 0 \\
\hline $\begin{array}{l}\text { K\&H Fund } \\
\text { Management }\end{array}$ & 891,141 & 3,197 & $0.36 \%$ & 2 & 1 \\
\hline $\begin{array}{l}\text { OTP Real Estate } \\
\text { Investment Fund } \\
\text { Management }\end{array}$ & 605,292 & 0 & 0 & 0 & 0 \\
\hline $\begin{array}{l}\text { CIB Investment Fund } \\
\text { Management }\end{array}$ & 433,341 & 0 & 0 & 0 & 2 \\
\hline $\begin{array}{l}\text { Hold Fund } \\
\text { Management }\end{array}$ & 415,642 & 0 & 0 & 0 & 0 \\
\hline $\begin{array}{l}\text { Budapest Fund } \\
\text { Management }\end{array}$ & 317,032 & 0 & 0 & 0 & 1 \\
\hline $\begin{array}{l}\text { MKB-Pannónia } \\
\text { Investment Fund } \\
\text { Management }\end{array}$ & 307,139 & 2,624 & $0.85 \%$ & 1 & 0 \\
\hline $\begin{array}{l}\text { Aegon Hungary } \\
\text { Investment Fund } \\
\text { Management }\end{array}$ & 281,265 & 0 & 0 & 0 & 1 \\
\hline $\begin{array}{l}\text { Diófa Fund } \\
\text { Management }\end{array}$ & 281,107 & 0 & 0 & 0 & 1 \\
\hline Total & $5,641,429$ & 13,915 & $0.25 \%$ & 4 & 6 \\
\hline
\end{tabular}

Note: Source for AUM: MNB Golden books 2019. https://www.mnb.hu/en/supervision/time-series/ golden-books

Table 7 shows the ESG funds offered by the ten largest asset management companies in Hungary. The total share of ESG funds was only 0.25 per cent in 2019, even less the MNB's calculation. The difference is due to the fact that their calculation occurred as of 31 January 2019, while I used end of year data. Also, only the ten largest asset management firms are included in Table 7, but there are several other, smaller players on the market. The table shows that there were only four ESG funds offered by Hungarian asset management firms, all of which are actively managed. However, several fund management firms started to offer ESG funds or expanded their already existing ESG product portfolio in 2020. The number of ESG funds increased from four to ten in a span of just one year, showing 
that fund managers see a potential increase in demand for ESG investments. While most of the new funds are still actively managed, the first Hungarian passive ESG fund was created in 2020 as well. Also, it is worthwhile to mention that some larger European fund management firms have subsidiaries among the ten largest ones in Hungary, and Hungarian investors can access ESG funds of the parent companies through the subsidiaries if they wish to gain ESG exposure. However, as these are not managed in Hungary, they are usually denominated in EUR.

In 2020, 66 per cent of the Hungarian population had some savings, increasing by 13 percentage points since 2017 and by 24 percentage points since $2015 .{ }^{21}$ However, most savers do not invest in anything, instead opting to keep their money on their bank account ( 35 per cent of those with savings) or in cash ( 25 per cent). This behaviour cannot be considered financially sound but if they decided to start investing a portion of their savings, smart beta ESG investing would be a good starting point:

1. As shown before, smart beta funds have relatively low ( 0.3 per cent on average) expense ratios which can be attractive to new investors who do not want to give away a significant portion of their returns to fund managers.

2. One disadvantage of ESG funds according to MNB's consultation document is the extra resources needed by them due to the difficulty of researching and selecting the adequate stocks. However, with a smart beta method this is no longer a problem if the ESG rating agency is trusted by the managers of the funds and the factor is the ESG rating itself, making the strategy a less resourceintensive endeavour for fund managers (MNB 2019:12).

3. The returns of the last few years, as examined before, seem to indicate that ESG investments are at least as profitable as regular investments, while combined with smart beta they have the potential to outperform the benchmark (as presented in the case of the EURO STOXX 50) and can survive external shocks better due to the lower risk levels associated with them.

However, for both demand and supply-side benefits to manifest, fund managers must provide the opportunity for investors to explore these options. Currently, no smart beta ESG funds can be found on the Hungarian market, but the increasing number of ESG funds and the appearance of the first passive ESG fund are promising steps in financial product development. The data presented in Figure 3 show that Hungary is lagging behind most European countries in terms of ESG, but the efforts of the MNB, BAMOSZ and the fund managers themselves show that they realise

\footnotetext{
${ }^{21}$ Based on A magyarok 66 százaléka rendelkezik megtakarítással (66 Per Cent of Hungarians Have Savings). https://www.budapestbank.hu/sajtoszoba/1097-202002201453 and A magyar lakosság pénzügyi kultúrája (The Financial Culture of Hungarian Population). https://penziranytu.hu/magyar-lakossag-penzugyikulturaja. Downloaded: 28 December 2020.
} 
the growing importance of ESG and are working towards improving the current situation.

\section{Conclusions}

The obvious benefit of ESG investing is that investors can support the movement for enhanced corporate activity by avoiding socially destructive companies, but it has also been shown that ESG indices mostly matched or outperformed their benchmarks in recent years. It also seems that during an external shock (like the Covid-19 pandemic) investments with higher social responsibility can reduce losses.

As determining the ESG performance of companies is a task far too challenging for individuals, ESG rating agencies have emerged. Their services are mostly available only for a fee but investors that do not wish to pay a premium can still access the final results of the $\mathrm{MSCI}$ ESG rating methodology.

Passive investing has been gaining ground on active investing in the last decade, but there is an alternative approach to choosing between the two sides: the smart beta strategy. It has some characteristics from both approaches, but its uniqueness comes from a factor that modifies the original weighting of the benchmark index. This way, investors can avoid involuntarily allocating most of their capital invested in an index to the few companies with extremely high market cap, while paying less in management fees than for active funds.

Because the factor chosen for weighting in the smart beta method can take many forms, ESG ratings can be used to include ESG in the portfolio. With this approach, I found that in case of the EURO STOXX 50 index, the benchmark can be significantly outperformed by ESG rating-weighted portfolios. Based on this result, I recommend constructing funds that follow this approach in practice as well, because the excess returns and the focus on ESG can attract new customers for fund managers. However, while ESG ratings were found to be significant, other variables such as size and earnings growth had more impact on the returns.

Having examined the situation of ESG investments in Hungary, I conclude that there are not currently very many options for ESG investing in the country for retail investors; that said, fund managers and the MNB are working on changing the status quo. Smart beta ESG investing can be a good starting point for new investors as it can provide substantial financial gains in addition to the lower management fees compared to actively managed funds. The establishment of such funds does not require vast resources from fund managers as the ESG ratings are readily available and only their methodology needs to be reviewed. 


\section{References}

Al-Khazali, O. - Zoubi, T. (2005): Empirical Testing Of Different Alternative Proxy Measures For Firm Size. Journal of Applied Business Research, 21(3): 79-90. https://doi.org/10.19030/ jabr.v21i3.1471

Anadu, K. - Kruttli, M. - McCabe, P. - Osambela, E. (2020): The Shift from Active to Passive Investing: Risks to Financial Stability? Financial Analysts Journal, 76(4): 23-39. https:// doi.org/10.1080/0015198X.2020.1779498

Arribas, I. - Espinós-Vañó, M.D. - García, F. - Tamošiūnienė, R. (2019): Negative screening and sustainable portfolio diversification. Entrepreneurship and Sustainability Issues, 6(4): 1566-1586. https://doi.org/10.9770/jesi.2019.6.4(2)

Bender, J. - Sun, X. - Wang, T. (2017): Thematic Indexing, Meet Smart Beta! Merging ESG into Factor Portfolios. The Journal of Index Investing, 8(3): 89-101. https://doi.org/10.3905/ jii.2017.8.3.089

Bernow, S. - Klempner, B. - Magnin, C. (2017): From 'why' to 'why not': Sustainable investing as the new normal. McKinsey \& Company. https://www.mckinsey.com/ /media/McKinsey/ Industries/Private\%20Equity\%20and\%20Principal\%20Investors/Our\%20Insights/From\%20 why\%20to\%20why\%20not\%20Sustainable\%20investing\%20as\%20the\%20new\%20normal/ From-why-to-why-not-Sustainable-investing-as-the-new-normal.ashx. Downloaded: 28 December 2020.

Breedt, A. - Ciliberti, S. - Gualdi, S. - Seager, P. (2019): Is ESG an Equity Factor or Just an Investment Guide? The Journal of Investing ESG Special Issue, 28(2): 32-42. https://doi. org/10.3905/joi.2019.28.2.032

Cheah, E.-T. - Jamali, D. - Johnson J.E.V. - Sung, M.-C. (2011): Drivers of Corporate Social Responsibility Attitudes: The Demography of Socially Responsible Investors. British Journal of Management, 22(2): 305-323. https://doi.org/10.1111/j.1467-8551.2011.00744.x

Douglas, E. - Van Holt, T. - Whelan, T. (2017): Responsible Investing: Guide to ESG Data Providers and Relevant Trends. Journal of Environmental Investing, 8(1): 92-115. https:// cbey.yale.edu/sites/default/files/Responsible\%20Investing\%20-\%20Guide\%20to\%20 ESG\%20Data\%20Providers\%20and\%20Relevant\%20Trends.pdf. Downloaded: 28 December 2020.

Escrig-Olmedo, E. - Munoz-Torres, M.J. - Fernandez-Izquierdo, M.A. (2010): Socially responsible investing: sustainability indices, ESG rating and information provider agencies. International Journal of Sustainable Economy, 2(4): 442-461. https://doi.org/10.1504/ IJSE.2010.035490 
Escrig-Olmedo, E. - Fernandez-Izquierdo, M. - Ferrero-Ferrero, I. - Rivera-Lirio, J. - MuñozTorres, M. (2019): Rating the Raters: Evaluating how ESG Rating Agencies Integrate Sustainability Principles. Sustainability, 11(3): 915-931. https://doi.org/10.3390/ su11030915

Giese, G. - Ossen, A. - Bacon, S. (2016): ESG as a Performance Factor for Smart Beta Indexes. The Journal of Index Investing, 7(3): 7-20. https://doi.org/10.3905/jii.2016.7.3.007

Levy, A. - Konish, L. (2020): The five biggest tech companies now make up $17.5 \%$ of the S\&P 500 - here's how to protect yourself. CNBC. https://www.cnbc.com/2020/01/28/ sp-500-dominated-by-apple-microsoft-alphabet-amazon-facebook.html. Downloaded: 28 December 2020.

MNB (2019): Green Finance in Hungary. Consultation document by the central bank of Hungary. Magyar Nemzeti Bank. https://www.mnb.hu/letoltes/green-finance-in-hungaryconsultation-paper.pdf. Downloaded: 28 December 2020.

Naffa, H. - Fain, M. (2020): Performance measurement of ESG-themed megatrend investments in global equity markets using pure factor portfolios methodology. PLoS ONE, 15(12): 1-34. https://doi.org/10.1371/journal.pone.0244225

Rompotis, G. (2009): Active vs. Passive Management: New Evidence from Exchange Traded Funds. https://doi.org/10.2139/ssrn.1337708

Talbot, D. - Boiral, O. (2018): GHG Reporting and Impression Management: An Assessment of Sustainability Reports from the Energy Sector. Journal of Business Ethics, 147: 367-383. https://doi.org/10.1007/s10551-015-2979-4

Townsend, B. (2020): From SRI to ESG: The Origins of Socially Responsible and Sustainable Investing. The Journal of Impact and ESG Investing, 1(1): 1-16. https://www.bailard.com/ wp-content/uploads/2020/09/History-Socially-Responsible-Investing-and-ESG-Investing. pdf?pdf=SRI-Investing-History-White-Paper. Downloaded: 28 December 2020.

Trinks, P.J. - Scholtens, B. (2015): The Opportunity Cost of Negative Screening in Socially Responsible Investing. Journal of Business Ethics, 140: 193-208. https://doi.org/10.1007/ s10551-015-2684-3 